\title{
The Role of Ayurvedic "Samshodhan-Karm"* in Treatment of Leprosy
}

\author{
DIVAKAR OJHA, A.B.M.s. (в.H.U.)** \\ Lecturer, Department of Kayachikitsa (Int. Medicine) P.G.I.I.M., \\ Banaras Hindu University, Varanasi-5, India \\ GURMOHAN SINGH, M.D. \\ Reader in Dermatology \& Venereology, College of Medical Sciences, B.H.U., Varanasi-5, India
}

\section{INTRODUCTION}

Various $\operatorname{texts}^{19^{10}}$ of the ancient Indian system of medicine have indicated 'Samshodhan-

Karm' (purificatory measures) with great stress in the treatment of 'Kushthas' ${ }^{\mathbf{6}}$ (skin diseases including leprosy). These measures have been prescribed not only before the administration of specific drugs, but also to be repeated several times in between the actual drug therapy. This particular procedure consists of several processes. Those meant for the treatment of leprosy are 'Snehana' (oleation), 'Vamana' (emesis), 'Virechana' (purgation) and 'Raktamokshana' (blood-letting). However, as the majority of leprosy patients already suffer from anaemia it was not desirable to impoverish further the blood of such patients by bloodletting and, therefore, this procedure was not adopted in this study.

Leprosy is a chronic disease and a number of remedies have been tried from time to time without finding an ideal one. The first and foremost drug used in the treatment of this disease was the oil of 'Tubarak' (Hydnocarpus or Chaulmoogra oil). This remedy was extensively used all over the world and was the mainstay in the treatment of leprosy till it was replaced by sulphones about 20 years ago. At present DDS in small doses is almost universally used and is the drug of choice in the chemotherapy of leprosy. No other drug has been found better, whether given singly or in combination with other drugs. The aim behind planning the present study was to investigate the role of purificatory measures of the ancient Indian system of medicine in comparison with the general standard treatment of leprosy by using DDS.

\section{MATERIALS AND METHODS}

Twenty male patients of untreated, advanced, infiltrated and nodular forms of lepromatous leprosy were the subject of study. When selecting the patients care was taken to choose pairs of identical patients. They were grouped into pairs by keeping 1 person of each pair to 1 group and the other person in the other group at random. In this way, 2 groups of 10 patients each were made, 1 for the trial and the other for control.

Group 1 received purificatory measures of the ancient Indian system of medicine followed by DDS.

Group 2 received DDS alone.

The duration of disease in these patients was 3 to 5 years, and the age range was 18 to 48 years. Purificatory measures of the ancient Indian system of medicine were carried out in the case of each patient in Group 1 before starting the administration of the specific DDS therapy and each procedure was repeated twice during the whole period of study of one year. 'Snehana' (oleation) was carried out by two standard methods: 1. Inunction of 'Tubarak Taila' (Hydnocarpus oil) mixed with equal parts of 'Nimb Taila' (Azadirachta indica oil), and 2. Oral administration of medicated and

\footnotetext{
* Purificatory measures of the ancient Indian system of medicine.

** Formerly Junior Scientific Officer (Ayurvedic Research Unit), Central Leprosy Teaching and Research Institute, Chingleput, Madras, India.
} 
processed 'Mahatikta-Ghrita'" (a compound preparation of herbal drugs and ghee, i.e., clarified butter) in a gradually increasing dose. A total of $56 \mathrm{oz}$. of 'Mahatikta-Ghrita' was administered starting from $2 \mathrm{oz}$. on the first day and increasing by $2 \mathrm{oz}$. every successive day and thus completing the total amount within 7 days. Inunction and oral administration of 'Mahatikta-Ghrita' were carried out concurrently.

'Vamana' (emesis) was introduced after 24 hours of completion of 'Snehana' process. A powder made of equal parts of 'Patola Patra' (Trichosanthes diocias leaves), 'Pippalee' (Piper longum) and 'Nimba' (Azadirachta indica) bark with 'Madanphala' (Randia dumetorum) was administered orally for 'vamana' in the early morning only for a day. In each individual the dose differed but ranged between 10 to $20 \mathrm{~g}$. for the full process. A complete morning intake was weighed and measured prior to the start of the process and at the end the total output was weighed. Only when the output was found to be more than injut was the process considered complete and perfect otherwise 'vamana' (emesis) was repeated the same day. After this the patients were kept in bed for complete rest without any medication for one week, following which the 'Snehana' process was repeated and the patients were not given anything on the succeeding 3 days. On the fourth morning the 'Virechana' (purgation) process was commenced by oral administration of a powder made of 'Trivrit' (Operculina turpethum). Here also the dose differed in individual patients but ranged from 10 to $15 \mathrm{~g}$. If the number of stools passed was at least 15 , the process was considered complete and perfect, otherwise it was repeated. Following 'Virechana' the patients were advised complete bed rest of 1 week but without giving any medication. Thus the 'Samshodhan-Karma' was completed in 34 days. In the case of Group 1 the standard treatment of DDS was given by following a pattern of gradual increasing dose, starting from $10 \mathrm{mg}$. once a day and increasing by $10 \mathrm{mg}$. every week, till the dosage of $100 \mathrm{mg}$. daily was reached. In this dosage the drug was given for 6 days in a week ${ }^{8}$.

58 Leprosy Review
Patients in Group 2 were put on DDS from the very beginning following the same pattern.

\section{Records and Laboratory Investigations}

The history and clinical condition of the patients were recorded on history sheets. The clinical picture of the patients was depicted with the help of notations given in 'Notes on Leprosy'. Weight records were maintained. Bacterial Index (B. I.) was calculated in each case by taking smears from 6 sites and adding the degrees of positivity of all the smears and dividing the total by the number of smears examined. ${ }^{3}$ Haematological examinations including the erythrocyte sedimentation rate by Weatergren method were done. Urine and stool examinations were carried out.

All the above-mentioned records and laboratory investigations were done before starting the therapy and at 3 monthly intervals.

\section{Criteria for Assessment}

The criteria for the assessment of improvement were denoted as 'Stationary', 'Improved' and 'Deteriorated" ${ }^{5}$. These categories are defined in Table 1.

\section{RESULTS}

There were 10 patients in each group, some of whom discontinued the treatments after some time. In Table 2, statistical analysis of B. I. is reproduced. It will be seen from the Table 2 ' $\mathrm{A}$ ' that the mean B. I's before treatment, after 6 months and after 12 months of treatment in the 2 groups remain more or less the same. When the decrease in B. I. after 6 months and 12 months of therapy was tested for significance it was found that the 2 groups did not indicate any difference. Thus there is no evidence of difference in action between the 2 groups.

In Table 2 ' $\mathrm{B}$ ' analysis of only those patients who remained throughout the therapy is included, which shows again no significant difference between the 2 groups.

In Table 3 the findings of this study are tabulated. It will be seen that the majority of the patients in both the groups improved. 
TABLE 1

Criteria for the assessment of patients under treatment

\begin{tabular}{|c|c|c|c|}
\hline $\begin{array}{l}\text { Clinical } \\
\text { condition }\end{array}$ & Stationary & Improved & Deteriorated \\
\hline $\begin{array}{l}\text { Nodular } \\
\text { and } \\
\text { Infiltrative }\end{array}$ & No change & $\begin{array}{l}\text { Nodules and thickened areas flattening or } \\
\text { flattened, with wrinkling. Freedom from } \\
\text { reaction, relief of nerve pain and eye } \\
\text { symptoms and nasal obstruction. Bac- } \\
\text { teriologically still positive. }\end{array}$ & $\begin{array}{l}\text { Increase in thickening and/or number } \\
\text { of patches and nodules, ulceration of } \\
\text { nodules, occurrence of repeated re- } \\
\text { action. Onset of complications in } \\
\text { nerves (nerve pain), eye (iritis), nose } \\
\text { (nasal obstruction). Bacteriologically } \\
\text { more highly positive. }\end{array}$ \\
\hline $\begin{array}{l}\text { Diffuse } \\
\text { and } \\
\text { Macular }\end{array}$ & No change & $\begin{array}{l}\text { Almost complete subsidence of erythema, } \\
\text { shininess and thickening in the skin, } \\
\text { maybe with some wrinkling of the skin. } \\
\text { Freedom from reaction, relief of nerve } \\
\text { pain and eye symptoms and nasal } \\
\text { obstruction. Bacteriologically still posi- } \\
\text { tive. }\end{array}$ & $\begin{array}{l}\text { Increase in thickening, number or size } \\
\text { of patches, appearance of nodules, } \\
\text { occurrence of repeated reactions. Onset } \\
\text { of complications in nerves (nerve pain } \\
\text { and tenderness), eye (iritis) and nose } \\
\text { (nasal obstruction). Bacteriologically } \\
\text { more highly positive. }\end{array}$ \\
\hline
\end{tabular}

\section{Statistical analysis for bacterial index (B. I.)}

TABLE 2 'A'

\begin{tabular}{|c|c|c|c|c|}
\hline Group & No. of cases & Before treatment & After 6 months of treatment & After 12 months of treatment \\
\hline & & Mean B.I. & $\begin{array}{c}\text { Mean B.I. Mean of difference } \\
\text { (with initial) } \\
\pm \text { S.E. }\end{array}$ & $\begin{array}{c}\text { Mean B.I. Mean of difference } \\
\text { (with initial) } \\
\pm \text { S.E. }\end{array}$ \\
\hline $\begin{array}{ll}\text { Group } 1 \\
\text { Group } 2\end{array}$ & $\begin{array}{l}10 \\
10\end{array}$ & $\begin{array}{l}3.24 \\
3.15\end{array}$ & $\begin{array}{l}-0.262 \pm 0.08 \\
-0.265 \pm 0.06\end{array}$ & $\begin{array}{r}-0.541 \pm 0.09 \\
-0.435 \pm 0.09\end{array}$ \\
\hline \multirow[t]{2}{*}{ 't } & & & $\begin{array}{l}<1 \\
>0.05\end{array}$ & $\begin{array}{l}<1 \\
>0.05\end{array}$ \\
\hline & \multicolumn{3}{|r|}{ TABLE 2 'B' } & \\
\hline \multirow[t]{2}{*}{ Group } & No. of cases & Before treatment & After 6 months of treatment & After 12 months of treatment \\
\hline & & Mean B.I. & $\begin{array}{c}\text { Mean B.I. Mean of difference } \\
\text { (with initial) } \\
\pm \text { S.E. }\end{array}$ & $\begin{array}{c}\text { Mean B.I. Mean of difference } \\
\text { (with initial) } \\
\pm \mathrm{S} . \mathrm{E} .\end{array}$ \\
\hline $\begin{array}{l}\text { Group } 1 \\
\text { Group } 2\end{array}$ & $\begin{array}{l}6 \\
8\end{array}$ & $\begin{array}{l}3.17 \\
3.25\end{array}$ & $\begin{array}{r}-0.186 \pm 0.13 \\
-0.302+0.13\end{array}$ & $\begin{array}{r}-0.580 \pm 0.30 \\
-0.456+0.19\end{array}$ \\
\hline Group 2 & 8 & 3.25 & $-0.302 \pm 0.13$ & $-0.456 \pm 0.19$ \\
\hline 't & & & $<1$ & $<1$ \\
\hline $\mathrm{P}$ & & & $>0.05$ & $>0.05$ \\
\hline
\end{tabular}


TABLE 3

Summary of results after 12 months' treatment

\begin{tabular}{|c|c|c|c|c|c|c|c|c|}
\hline \multirow[b]{2}{*}{ Groups } & \multirow[b]{2}{*}{$\begin{array}{l}\text { Total } \\
\text { No. } \\
\text { of } \\
\text { cases }\end{array}$} & \multirow[b]{2}{*}{$\begin{array}{l}\text { Age } \\
\text { range } \\
\text { in } \\
\text { years }\end{array}$} & \multirow[b]{2}{*}{$\begin{array}{c}\text { Duration } \\
\text { of } \\
\text { disease } \\
\text { in years }\end{array}$} & \multicolumn{3}{|c|}{ CLINICAL } & \multicolumn{2}{|r|}{ DDS } \\
\hline & & & & Stationary & Improved & $\begin{array}{l}\text { Deterior- } \\
\text { ated }\end{array}$ & $\begin{array}{l}\text { No. of } \\
\text { cases who } \\
\text { had } \\
\text { reaction }\end{array}$ & $\begin{array}{lc}\text { Con- } & \text { Dis- } \\
\text { tinued } & \text { continued } \\
(\text { No. of cases })\end{array}$ \\
\hline Group 1 & 10 & $18-48$ & $3-5$ & $\mathrm{x}$ & 6 & 4 & 4 & 4 \\
\hline
\end{tabular}

All the patients withstood well the measures adopted, but some patients had to be withdrawn from the trial as they developed reactions. They indicated good absorption of the drug used during the 'Snehana' (oleation) measure, both externally and internally. In the patients of both the groups in which the clinical and bacteriological progress was noted, they were almost similar. Both the groups showed considerable improvement: the size of the nodules of the lepromata became markedly less, some of the smaller lenticulate nodules on cheeks and ears almost disappeared, infiltration decreased; repigmentation of lepromatous macular lesions also took place. No patient in any group remained stationary either clinically or bacteriologically, barring those who had had reactions. Out of 10 patients in Group 1 , 2 improved and 4 deteriorated, while out of 10 patients in Group 2, 8 improved and 2 deteriorated (Table 3). The DDS was stopped in all the deteriorated patients in whom lepra reactions occurred. Reduction in the Bacterial Index and degenerative changes in $M$. leprae ran parallel with clinical improvement in both the groups. The weight and haemoglobin gradually increased in both the groups during the first 6 months, but during the next 6 months of the treatment it gradually decreased.

\section{Toxicity and Complications}

No signs of toxicity developed during the treatment except reactions in some patients.

\section{DISCUSSION}

The classics of the ancient Indian system of medicine reveal that 'Samshodhan-Karm' therapy is the main measure in the approach to the treatment and prevention of diseases and maintenance of health. Yet while the physicians of the northern part of this country do not practise this therapy, their colleagues in South India are well known for the successful use of these measures. In view of these facts the present scientific inquiry was pursued on different measures (which are indicated in the treatment of leprosy) of this therapy. The combined administration of DDS and Ayurvedic 'Samshodhan-Karm' has not shown any significant beneficial effect either clinically and/or bacteriologically in comparison with the administration of DDS alone. The rate of improvement does not seem to have been accelerated by adding Ayurvedic 'Samshodhan-Karm' in any way.

Reaction was encountered but could not be definitely attributed to the Ayurvedic 'Samdhodhan-Karm' as very little is known about its direct cause, but reaction is most commonly associated with chemotherapy and the administration of sulphones. ${ }^{4}$ This view is supported by the fact found in the present study as whenever during reaction the drug DDS was temporarily suspended it resulted in the disappearance of the inflammatory signs. However, it is felt that this particular procedure of the ancient Indian system of medicine should be given further trial by planned methods in a longer series of lepromatous patients before rejecting finally the aforesaid procedure. 


\section{SUMMARY}

Some preliminary preparation of the patient for 'Samshodhan-Karm' (purificatory measures) is an essential pre-requisite for the Indian system of adoption of any specific therapy of leprosy in Ancient Medicine. This particular procedure has been evaluated under this study. The DDS given alone was taken as the control drug against which the results obtained with Ayurvedic 'Samshodhan-Karm' with DDS were compared after 6 months and 12 months of treatment. The assessment made at various intervals after treatment has not shown any appreciable improvement (clinical and/or bacteriological) in any of the patients. At the same time there was no untoward effect encountered which could be definitely attributed to the Ayurvedic 'Samshodhan-Karm'.

\section{ACKNOWLEDGEMENT}

The help in statistical analysis from Mr. E. G. Phadia, Statistician, P.G.I.I.M., Banaras Hindu University, Varanasi, is acknowledged with thanks.

\section{REFERENCES}

1. Charaka, Charak Samhita, Sutra Sthana, Chapt. 13, Choukhambha Sanskrit Series, Varanasi Press (1961), 81-87.

2. DAs, G. Bhaishajyaratnawali, verses $1-4,77,78$, 243-249, published by Choukhambha Sanskrit Pustakalaya, Banaras-1 (1951), 618-540.

3. DhARMEndra. Notes on Leprosy, published by the Ministry of Health, Government of India, New Delhi (1960), 176-181.

4. MUIR, E. Lepra Reaction and the general adaptation syndrome. Lep. Rev., 33, (1962) 240-251.

5. оЈнA, D. Investigations on some indigenous drugs in the treatment of leprosy. Ind. J. of Derm. and Ven., 31, (1965) 229-238.

6. олна, D. Leprosy in Ayurveda, Nagarjun (1964), 935-945.

7. олна, D. Nimbadi-Lepa in the treatment of Leprosy-a preliminary report. Ind. J. Med. Sc., 20, (1966) 217-221.

8. оJнA, D., et al. Role of an indigenous drug (Achyranthes aspera) in the management of reactions in leprosy. Lep. Rev., 37, (1966) 115-120.

9. Sushruta, Sushruta Samhita, Sutra Sthana, edited by Ghanekar, Bhaskara Govind, Banaras Hindu University, Chapt. 5 (1950), 28-36.

10. Vagabhata, Astangahridayam, Chikitsita sthanam, Chapt. 19 (1954), 384-391. 